CZASOPISMO INŻYNIERII LACDOWEJ, ŚRODOWISKA I ARCHITEKTURY JOURNAL OF CIVIL ENGINEERING, ENVIRONMENT AND ARCHITECTURE JCEEA, t. XXXII, z. 62 (3/II/15), lipiec-wrzesień 2015, s. 379-391

\author{
Alexander A. RIABENKO ${ }^{1}$ \\ Volodymyr V. CHERNYUK ${ }^{2}$ \\ Oksana A. KLYUHA ${ }^{3}$ \\ Oksana A. HALYCH ${ }^{4}$ \\ Dmytro M. POPLAVSKIY ${ }^{5}$
}

\title{
MATHEMATICAL AND HYDRAULIC MODELLING OF UNDULAR JUMP
}

\begin{abstract}
The article considers the problem of undular jump's mathematical and hydraulic modelling. The cases of undular jump formation during different hydrotechnical constructions work are given. If the specifity of undular jump, especially wavelike free-surface and departure of from pressure distribution will not be taken into account, it can put to difference between designed and real hydraulic regimen. This factor can bring to miscalculation during designing, building and exploitation of constructers. All that shows the issue urgency of undular jump characteristics calculations and modelling. The article gives existent differential equations of free-surface of near-critical flows, which include undular jump.

The disadvantage of given differential equations and their solutions are made, based on produced analysis. Consequently, addressing the mentioned existing misconceptions about the undular jump, it is necessary take into account inclination and curvature of streamlines in initial section of considered phenomena. The original mathematical model of near-critical flow, which takes into account this factor, are suggested. On the basis of this model, the differential equation was derived - with its general and specific solutions - for the free-surface profile of the considered phenomena.

The results of undular jump laboratory researches, which were made on experimental setup, are demonstrated. The comparison of theoretical calculations with experimental data has provided a good convergence of the results.
\end{abstract}

Keywords: modelling, undular jump, solitary wave, cnoidal waves, mathematical modelling, laboratory investigation.

\footnotetext{
${ }^{1}$ Author for correspondence: Alexander A. Riabenko, National University of Water management and Nature Resources Use, Rivne, Ukraine

${ }^{2}$ Volodymyr V. Chernyuk, Lviv Polytechnic National University, Lviv, Ukraine

${ }^{3}$ Oksana A. Klyuha, National University of Water management and Nature Resources Use, Rivne, Ukraine

${ }^{4}$ Oksana A. Halych, National University of Water management and Nature Resources Use, Rivne, Ukraine

${ }^{5}$ Dmytro M. Poplavskiy, National University of Water management and Nature Resources Use, Rivne, Ukraine
} 


\section{Introduction}

The mathematical and hydraulic modelling very often are used during investigation of difficult hydraulic phenomena. The results of hydraulic modelling are useful for getting the net results during consideration the particular practical task and also for the actual material, which is necessary to correcting the existing and development of new theories.

Recently, a lot of publications about undular jump have evidenced, that a considerable attention has been paid to discovering of this phenomenon. Undular jump is transitional phenomenon from supercritical to subcritical flows and is characterized by undulations of water free-surface with a gradual attenuation of waves (fig. 1). The depth at the beginning of undular jump is $h_{1}<h_{c r}$, and in the bending points of the free-surface curve is $h_{2}>h_{c r}$, where $h_{\mathrm{cr}}-$ is critical depth. The maximum depth $h_{c}$ is usually located beneath the crest of the first wave.

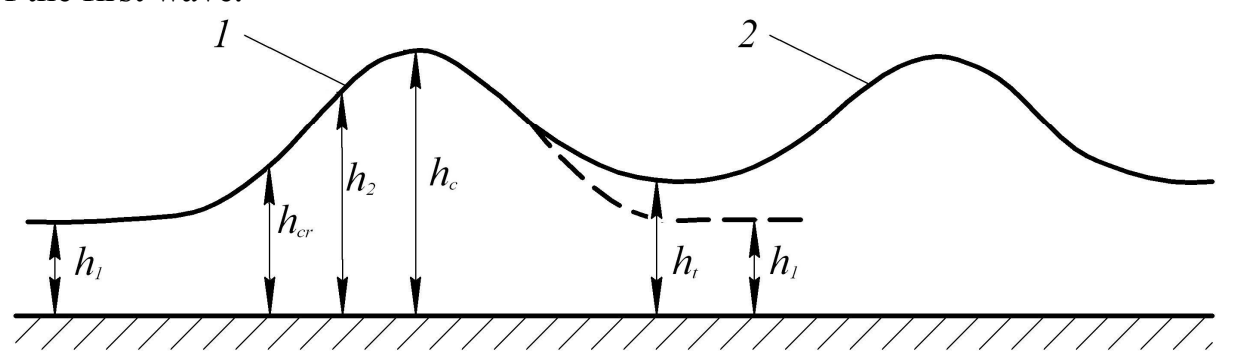

Fig. 1. Scheme of undular jump: 1 - solitary wave, 2 - conoidal waves

Rys. 1. Schemat skoku falistego: 1 - fala pojedyncza, 2 - fala konoidalna

The beginners who started researching this phenomenon were Darcy and Bazin, Bőss, Bakhmetev, Sukhomel [2, 3, 5, 15]. Lately, a considerable attention has been paid to the development of theoretical methods for modelling of the free-surface profile of the undular jump, based on analytical $[7,8,11]$ and numerical solutions [10] of the relevant differential equations, which are part of this phenomenon's mathematical modelling. The hydraulic modelling of undular jump in the process of this problem's research in laboratory conditions are described in works $[4,6,13]$.

\section{The occurrences of undular jump formation. Urgency of an issue}

Analysis of information demonstrates that undular jump under suitable conditions can occur to the extent of different hydrotechnical constructions (fig. 2). Wave propagation for long distances can bring to appearance of different dynamic stress. And this can bring to destroy of structural members and channel stream bank erosion. 

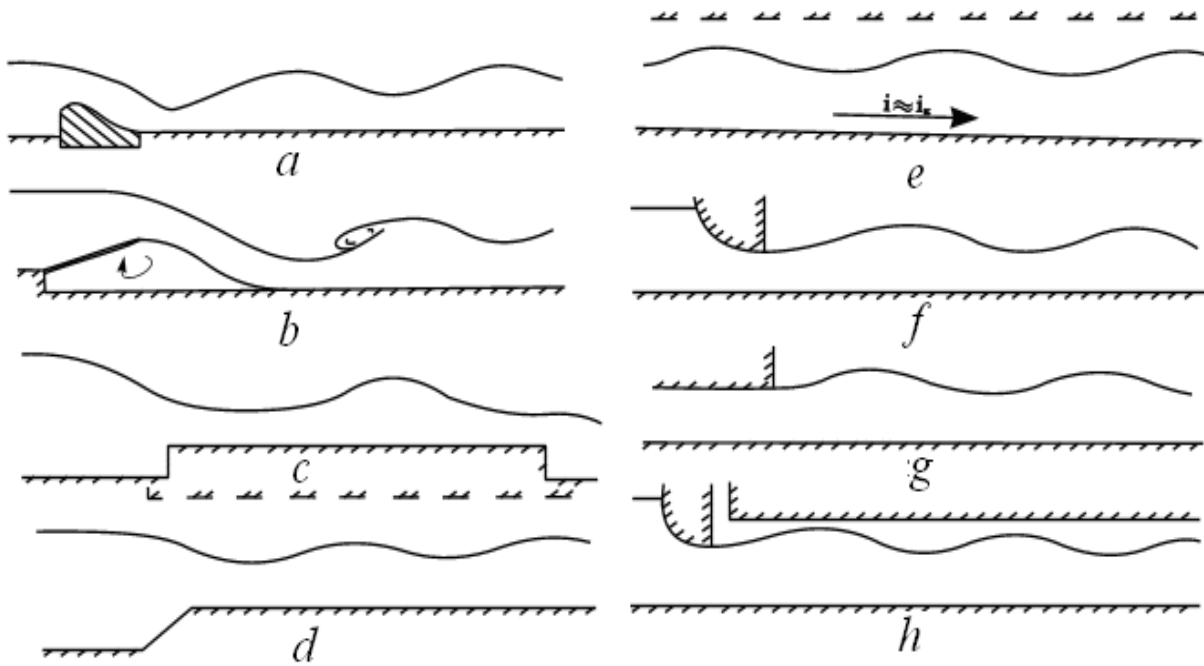

Fig. 2. The occurrence of undular jump formation: $a-$ downstream from weirs, $b$ - downstream from offtake regulators and low-head spillways, $c-$ on broad-crested weirs, $d-$ at the entry of channels or free-flow tunnels, e - in free - flow channels, tunnels, pipelines, culverts, $\mathrm{f}$ - downstream from water-gates with smooth or broken shape of low part, $g-$ at the entry of tunnels' and tubes' sluice port, $\mathrm{h}$ - in tunnels with boom

Rys. 2. Istniejące formacje skoku falistego: $\mathrm{a}$ - od jazu z nurtem, b - od regulatorów wypływu i niskogłowicowych przelewów spustowych z nurtem, c - od szeroko zwieńczonych jazach, d - na wejściu kanałów lub tunelach wolnoprzepływowych, e - w wolnoprzepływowych kanałach, tunelach rurociągach, przepustach, $\mathrm{f}$ - od bramy wodnej z gładkim albo łamanym kształtem dolnej części z nurtem, $g$ - przy wejściach tuneli, rur, poru śluzy, $\mathrm{h}$ - w tunelach z zasuwą

If the specifity of undular jump, especially wavelike free-surface and departure of from pressure distribution will not be taken into account, it can put to difference between designed and real hydraulic regimen. This factor can bring to miscalculation during designing, building and exploitation of constructers. All that shows the issue urgency of undular jump characteristics calculations and modelling.

\section{Difference equations of undular hydraulic jump}

Development of calculation relations, which describe the free-surface profile of the undular jump and other types of hydraulic phenomena with a wavelike surface (round-crested and broad-crested weirs, solitary wave, cnoidal waves, translation waves etc.), is based on basic equations of the classic hydraulics, such as: equations of energy and momentum preservation, equation of continuity, the Euler's formula, and equations of Bernoulli and Saint-Venant. The nonlinear partial differential equations of Boussinesq and Korteweg-de 
Vries are usually applied in relations for the unsteady flows with a wavelike surface. For the steady flows the time component is not considered, which significantly simplifies the equations. Relevant to the task, the most characteristic differential equations are provided from the previous analysis in this article.

The Korteweg - de Vries equation, general:

$$
h_{t}=K_{1} h h_{x}-K_{2} h_{x x x}=0,
$$

where: indices near depth $h$ mean derivative of this parameter;

The Korteweg - de Vries equation by Bhatnagar [1] in the form of cubic polynom

$$
h^{\prime 2}=\frac{1}{3 \delta}\left(-h^{3}+3 C h^{2}+6 A h+6 B\right)
$$

The Serre's equation [14] expressed via specific energy E

$$
h^{\prime 2}=\frac{6 g}{q^{2}}\left(-\frac{h^{3}}{2}+E h^{2}+C_{1} h+\frac{q^{2}}{2 g}\right)
$$

The Serre's equation [14] expressed via momentum M

$$
h^{\prime 2}=\frac{3 g}{q^{2}}\left(-\frac{h^{3}}{2}+C_{2} h^{2}-M h+\frac{q^{2}}{2 g}\right) .
$$

where: $\delta, A, B, C, C_{1}, C_{2}-$ are integration coefficients and constants.

The differential equations (1) - (4) describe quite a large number of hydraulic processes with a nonlinear free-surface. If for a linear channel's floor with no or insignificant inclination, the solutions for the equations (1) - (4) can be transformed to well-known formulas of the solitary wave:

$$
h=h_{1}+\left(h_{c}-h_{1}\right) \operatorname{sch}^{2}\left[\frac{x}{2} \sqrt{\frac{3 g}{q^{2}}\left(h_{c}-h_{1}\right)}\right]
$$

and conoidal waves:

$$
h=h_{1}+\left(h_{c}-h_{1}\right) c n^{2}\left(\frac{x}{\Delta}, k\right)
$$

where: $\Delta$ and $k$-are parameters of the waves. 
The mentioned previous analysis allowed concluding the following shortcomings of the differential equations (1) - (4) and their solutions:

a) Application of the equations (3) - (5) is complicated by presence of unknown parameters $K_{1}, K_{2}, A, B, C, E, M, \delta M$ and the integration constants $C_{1}, C_{2}$. Those variables can be found by different methods depending on the type of phenomenon, applied mathematical model, and approach for defining the limiting conditions. Solutions for the variables are usually found for simplified conditions - for the sections of the flow with slowly changing motion and hydrostatic pressure distribution. Such approach is reasonable for many practical situations. However, for the phenomena where such sections do not exist (e.a. cnoidal waves, undular jump with non-hydrostatic pressure distribution in the initial section), that approach cannot be applied as will lead to inconsistencies and errors.

b) The formulas (5) and (6) cannot be considered as the complete solution for the differential equations (1) - (4), as they include the maximum depth $h_{c}$, which is a priori unknown and finding its value is one of the main practical tasks of practical calculations.

c) Dimensional and dynamic conditions of the flow in the initial section of the considered phenomena (with the depth $h_{l}$ ) remain unknown. Additionally, it is unknown and not accounted if there are inclination and curvature of streamlines (non-hydrostatics) in the initial section.

Consequently, addressing the mentioned existing misconceptions about the undular jump, the wrong stereotypes, and inappropriately used differential equations - requires the development of a principally original and conceptual new mathematical model for the wavelike near-critical flows. It is imperative that such model would have to account for possible inclination and curvature of streamlines in the initial section of the considered phenomena.

\section{Mathematical model of the near-critical flows that accounts pos- sible non-hydrostatic pressure distribution in the initial section}

Identification and accounting for inclination and curvature of streamlines are critically important for modern research of the undular jump and other nearcritical phenomena. This problem is generally considered in hydraulics, fluid mechanics, and some specific works, but only for a random section of a flow. It is the Riabenko's genuine approach, applied in the provided original mathematical model, to relate and account for possible hydrostatic and nonhydrostatic conditions specifically in the initial section of the undular jump and other types of the near-critical flows.

The calculation scheme for the model is provided on the Fig. 3. It assumes a flat linear channel with the bottom's slope $0 \leq i<i_{c r} ; 0 x$ axis corresponds to the bottom of the channel and is in direction of the flow; $0 y$ - in accordance with existing theoretical schemes - goes through the crest of the first wave. 
In a case for hydrostatics in the initial section - section $0-0$ with no inclination and curvature of the streamlines $-h^{\prime}=h^{\prime \prime}=0$; in a case for non-hydrostatics in the initial section - section 1-1 with no inclination but considerable curvature of the free-surface curve $-h^{\prime}=0, h^{\prime}>0$.

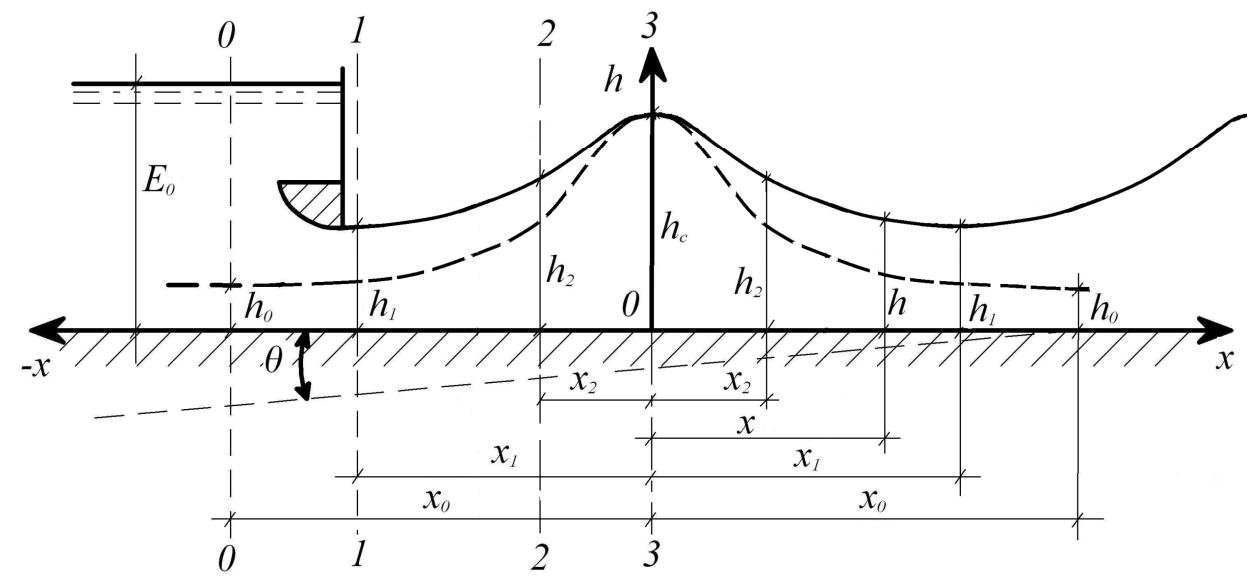

Fig. 3. The calculation scheme for wavelike near-critical flows

Rys. 3. Schemat obliczania falistego przepływu blisko krytycznego

Developed in accordance to the set requirements, the mathematical model for the wavelike near-critical flows is based on the well-known Serre's relations [14] for specific energy $E$ and moment $M$, which account (for) inclination and curvature of streamlines via, accordingly, the first $h$ ' and the second $h$ "derivatives of the $h(x)$ function of the free-surface curve. Mathematical description of the problem can be expressed either via energy $E$ :

$$
\begin{aligned}
& E=h+\frac{q^{2}}{2 g h^{2}}+\frac{q^{2} h^{\prime \prime}}{3 g h}-\frac{q^{2} h^{\prime 2}}{6 g h^{2}} \\
& \frac{d E}{d x}=i-i_{f} \\
& \frac{d q}{d x}=0
\end{aligned}
$$

where: $i_{f}-$ friction slope.

Limiting conditions. At the selected position of coordinate axes, the limiting conditions for the characteristic sections of the considered phenomena can be expressed as following: 

a) $x=0, h=h_{c}, h^{\prime}=0, h^{\prime \prime}<0, E=E_{c}, M=M_{c}$;
b) $x=x_{2}, h=h_{2}, h^{\prime}>0, h^{\prime \prime}=0, E=E_{2}, M=M_{2}$;
c) $x=x_{1}, h=h_{1}, h^{\prime}=0, h^{\prime \prime}>0, E=E_{1}, M=M_{1}$;
d) $x=x_{0}=\infty, h=h_{0}, h^{\prime}=0, h^{\prime \prime}=0, E=E_{0}, M=M_{0}$.

The indexes " 0 ", " 1 ", "2", and "c" in the above relations and henceforth imply that values correspond, accordingly, to the sections $0-0,1-1,2-2$, and 3-3. Additionally, it is assumed that the pressure distribution in the section 2-2, which is the section at the inflection point of the free-surface curve, is approximately hydrostatic.

Applied method to determine energy, momentum, and integration constants. Distinctive features of the developed mathematical model, applied method of integration, received differential equations, and their solutions are the following. Determination of the energy $E$, the momentum $M$, and the relevant integration constants is processed not for a nominal section placed at infinity with slowly changing motion and hydrostatic pressure distribution, but for a real initial section 1-1 of the considered phenomena. It is advantageous that characteristics of the section can be evaluated in both theoretical and practical way. It is considered that pressure distribution in the initial section 1-1 is either hydrostatic or non-hydrostatic. Presence, absence, and the level of possible deviation from hydrostatics in a random section of the wavelike nearcritical flows is evaluated with the cross-linked coefficients of non-hydrostatics $s$, hydrodynamic pressure $t$ and potential energy $\beta$.

The mentioned coefficients have the following relations for the parabolic law of pressure distribution in depth [13]:

$$
\beta=\frac{1+2 s}{3} ; \quad t=\frac{4 s-1}{3} ; \quad \beta=\frac{1+t}{2},
$$

besides, for the hydrostatics - the coefficients $s, t, \beta$ is equal unit.

In accordance with the provided information and additionally assuming that $E=$ const, $i=0$ energy $E$ and integration constants $C_{l}$ can be expressed for the section 1-1 in the following way:

$$
\begin{aligned}
& E=E_{1}=\beta_{1} h_{1}+\frac{q^{2}}{2 g h_{1}^{2}}, \\
& C_{1}=\left(\frac{1}{2}-\beta_{1}\right) h_{1}^{2}-\frac{q^{2}}{g h_{1}},
\end{aligned}
$$




\section{Generalized differential equation of the free-surface profile and its solutions}

Consideration of the system (7) for the limiting conditions (8) and with application of the relations (9) - (11) in work [13], has resulted with the development of the generalized differential equation for the free-surface profile of the wavelike near-critical flows:

$$
h^{\prime 2}=\frac{3}{F r_{1}}\left[-\eta^{3}+\left(2 \beta_{1}+F r_{1}\right) \eta^{2}-\left(2 \beta_{1}-1+2 F r_{1}\right) \eta+F r_{1}\right]
$$

where: $\eta=h / h_{1}, \mathrm{Fr}_{1}$ - the Froude number in the section 1-1, calculated by formula

$$
F r_{1}=\frac{v_{1}^{2}}{g h_{1}^{3}}=\frac{q^{2}}{g h_{1}^{3}} \text {. }
$$

With performed integration of the differential equation (12), it has been obtained the general solution of the equation in the form of the system presented below [13]:

$$
\left.\begin{array}{rl}
\eta & =\frac{h}{h_{1}}=1+\left(\eta_{c}-1\right) \mathrm{cn}^{2}\left(\frac{x}{\Delta}, k\right), \\
\Delta & =2 h_{1} \sqrt{\frac{\eta_{c} F r_{1}}{3\left(\eta_{c}^{2}-F r_{1}\right)}}, \\
k & =\sqrt{\frac{\eta_{c}\left(\eta_{c}-1\right)}{\eta_{c}^{2}-F r_{1}}}, \\
\eta_{c} & =\frac{1}{2}\left[t_{1}+F r_{1}+\sqrt{\left(t_{1}+F r_{1}\right)^{2}-4 F r_{1}}\right] .
\end{array}\right\}
$$

This solution corresponds to the position of the coordinate axes as shown on the Fig. 3. and it describes cnoidal waves and is true for the following conditions:

$$
\left.\begin{array}{l}
F r_{1} \leq 1, \\
s_{1} \geq 1 .
\end{array}\right\}
$$

If pressure distribution in the initial section of the considered phenomena is hydrostatic $\left(s_{I}=t_{I}=\beta_{I}=1.0\right)$, the differential equation (14) can be significantly simplified and expressed in the following form: 


$$
h^{\prime 2}=\frac{3}{F r_{1}}(\eta-1)^{2}\left(F r_{1}-\eta\right),
$$

and its solution can be drawn to the well-known relation (5) for the solitary wave.

It is important to accentuate that the undertaken analysis has revealed that for the applied condition $s_{1}=1,0$ in the equation (16) it absolutely required that $F r_{1}>1$; hence the physical meaning of the solution for the solitary wave is possible only if:

$$
\left.\begin{array}{l}
S_{1}=1,0, \\
F r_{1}>1,0 .
\end{array}\right\}
$$

\section{Experimental setup and research technique}

Hydraulic modelling of undular jump, as an other types of open channel flows, usually is made by Froude criteria $\mathrm{Fr}_{1}[9,12]$. Laboratory researches of undular jump were performed in the National University of Water and Water Management and Nature Resources Use. Investigations for plane-point conditions were conducted on the experimental setup, which is described in work [13]. This setup is constructed as rectangular channel. The length of the channel is $39,0 \mathrm{~m}$, the width is $1,0 \mathrm{~m}$ and the height is $1,0 \mathrm{~m}$. The first part of the channel (fixed part) has length $23,1 \mathrm{~m}$ and it is installed on steel truss, and other part (mobile part) has length $15.9 \mathrm{~m}$ and has ability to change its bad slope. The channel bottom is concrete with smooth surface. In the experiments it was used 6 positions of water-gate along the length of the channel.

Investigated undular jump was formed by using scheme of water discharge from water-gate. Low part configuration of water-gate could be changed, when it is necessary. The depth of downstream was controlled by using pivot-leaf gate, which was installed at the end of the experimental setup. Besides, this depth could be regulated by changing the bad slope of channel ending part.

The experimental setup had 2 groups of piezometers (the whole amount 95) to measure the bottom-loading pressure along the centre line of flow. Intake openings were located with interval $5,0 \mathrm{~cm}$.

During investigation of undular jump with the use of water-gate the positions of undular free-surface over intake openings of piezometers were measured by mobile point-gauge.

On the ground of experimental data the locations of water free-surface and pressure gradient line were defined and other characteristics of investigate phenomenon. 


\section{Comparison theoretical and experimental data of undular jump free-surface profile}

The fig. 4 shows the comparison of two experiments of undular jump freesurface profiles with theoretical calculations of undular jump free-surface profiles by Hager-Hutter method [9], method by recommendations of Russian Scientific Research Institute of Hydrology, named by B.E. Vedeneev (VNIIG) [8] and suggest method, which is used equations system (14). Thereat, the undular jump is presented in the aggregate of solitary and cnoidal waves and the connection of these equations' solutions is doing in section of jump's first crest. The cositing of comparison profile is made also in this section.
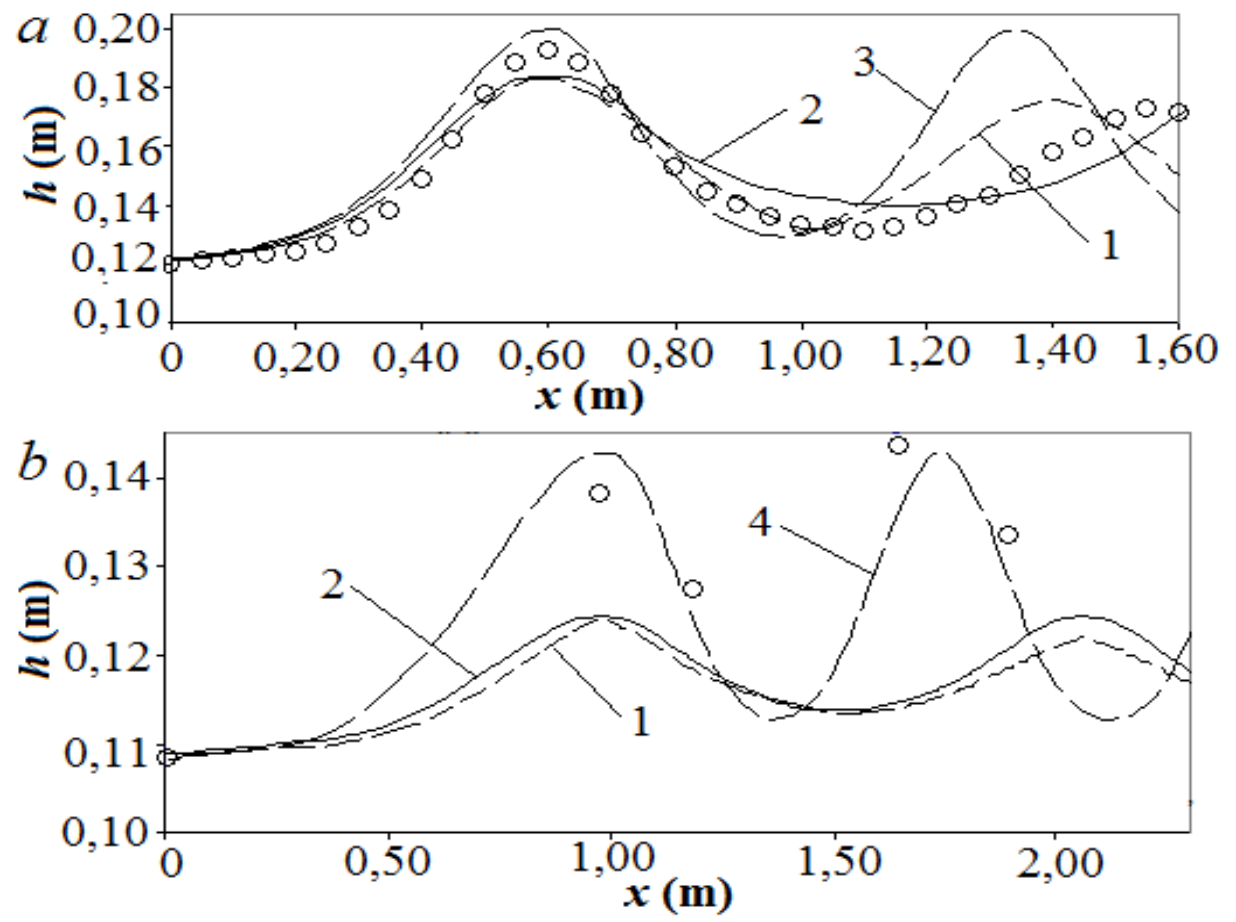

Fig. 4. Undular jump free-surface profiles: a - experimental test by Riabenko $[13]\left(\mathrm{q}=0,161 \mathrm{~m}^{2} / \mathrm{s}\right.$, $\left.\mathrm{h}_{1}=0,12 \mathrm{~m}, \mathrm{Fr}_{1}=1,53, \mathrm{~s}_{1}=1,07\right) ; \mathrm{b}-$ experimental test by Chanson $[4]\left(\mathrm{q}=0,12 \mathrm{~m}^{2} / \mathrm{s}\right.$, $\left.\mathrm{h}_{1}=0,1086 \mathrm{~m}, \mathrm{Fr}_{1}=1,16, \mathrm{~s}_{1}=1,0\right) ; 1-4$ - profiles built using theoretical relations: 1 - HagerHutter [8]; 2 - VNIIG [7]; 3-4 - mathematical model eq. (14) $\left(3: \mathrm{s}_{1}=1,07 ; 4: \mathrm{s}_{1}=1,03\right)$; $\circ$ - experimental data points

Rys. 4. Profile skoku falowego wolnej powierzchni: a - badanie doświadczalne wg Riabienko [13] $\left(\mathrm{q}=0,161 \mathrm{~m}^{2} / \mathrm{s}, \mathrm{h}_{1}=0,12 \mathrm{~m}, \mathrm{Fr}_{1}=1,53, \mathrm{~s}_{1}=1,07\right) ; \mathrm{b}$ - badania doświadczalne wg Chanson [4] $\left(\mathrm{q}=0,12 \mathrm{~m}^{2} / \mathrm{s}, \mathrm{h}_{1}=0,1086 \mathrm{~m}, \mathrm{Fr}_{1}=1,16, \mathrm{~s}_{1}=1,0\right) ; 1-4$ - profile otrzymane $\mathrm{z}$ wzorów teoretycznych: 1 - Hager-Hutter [8]; 2 - VNIIG [7]; 3-4 - model matematyczny wg. (14) $\left(3: \mathrm{s}_{1}=1,07 ; 4: \mathrm{s}_{1}=1,03\right) ; \circ-$ punkty $\mathrm{z}$ badań doświadczalnych 
The analysis of getting information about undular jump free-surface profiles in domain of the small Froude numbers allowed making next provisions. The results of calculations by methods of Hager-Hutter, of VNIIG and also of Riabenko with non-hydrostatic coefficient $\mathrm{s}_{1}=1$ are very closed to each others. In case of non-hydrostatic presence in initial section of undular jump with very small Froude numbers, which are closed to unite (fig. 4b), Hager-Hutter and VNIIG methods, which are not take into account this factor, give unacceptable results. Riabenko's method takes into account possibility of nonhydrostatic in initial section and gives satisfactory convergence with experimental data. If suppose, that there was non-hydrostatic in initial section of undular jump in Chanson's experimental data (fig. 4b), and calculate free-surface profile by using Riabenko's method, then theoretical results The theoretical results would be corresponded preferably for non-hydrostatic coefficient $s_{1}=1,03$.

\section{Conclusions}

1. The developed mathematical model takes into account for possible inclination and curvature of streamlines (via coefficients $s_{1}, t_{1}, \beta_{l}$ ) and, accordingly, for possible deviation from hydrostatics in the initial section of the considered phenomena.

2. Comparison of the undular jump free-surface profiles built on the basis of the developed model (14) with ones built on the basis of experimental data within the same range of the main characteristics - provided a good convergence of the results and confirmed about a principal accurateness of the developed mathematical model.

3. Mathematical and hydraulic modelling, as well as calculations of undular jump and other types of near-critical flows, should be made by two factors in initial section - the Froude number $\mathrm{Fr}_{1}$ and non-hydrostatic coefficient $\mathrm{s}_{1}$, which takes into account inclination and curvature of streamlines in this section of the undular jump.

\section{Bibliography}

[1] Bhatnagar P.I. Nonlinear waves in one-dimensional dispersive systems. Clarendon Press, Oxford. 1979.

[2] Bőss P. Berechnung der Wasserspiegellage. Forschungsarbeiten. - Heft 284, NW7. Berlin. - 1927. -96 ps. (German).

[3] Bakhmetev B.A. On non-uniform liquid flow in open channel, KUBUCH, Leningrad, 1928. -275 ps. (Russian).

[4] Chanson H. Flow Characteristics of Undular Hydraulic Jump. Comparison with Near-Critical Flows. Report CH 45/95. University of Queensland, Australia. 1995. 202 ps.

[5] Darcy H., Bazin H. Recherches hydrauliques. Parties 1-e et 2-e. - Paris. Imprimerie Impériale. 1865. (French). 
[6] Gotoh H., Yasuda Y., Ohtsu I. Effect of channel slope on flow characteristics of undular hydraulic jumps. WIT Trans. Ecology Envir., Vol. 83, 2005. 33-43 ps.

[7] Gunko F.G. Hydraulic calculations of structures, control of turbulence flow. Recommendations for designing. Leningrad. Energia, 1974. - 110 ps. (Russian).

[8] Hager W.H., Hutter K. On pseudo-uniform flow in open channel hydraulics. Acta Mechanica. Vol.53, № 3-4, 1984. 183-200 ps.

[9] Riabenko A., Kravets S., Kojouchko L., Hassane M. Modélisation hydraulique de sécoulements du liquide au voisinage de la profondeur critique. Actes. Colloque Internationalsurl 'Eauetl'Environnement. Alger, 2004. - 180-188 ps. (French).

[10] Rostami F., Shahrokhi M., Saod M.A.M., Yazdi S.R.S. Numerical simulation of undular hydraulic jump on smooth bed using volume of fluid method. Appl. Math. Modelling. 37 (3), 2013. 1514-1522 ps.

[11] Ryabenko A.A. Free Surface Profile of Wavelike Near-Critical Flows and Solitary Solutions of some Differential Equations. Int. Journ. Fluid Mech. Research. Beggell House, Inc. Vol. 28, № 6, 2001. 834-856 ps. (Translated from Ukrainian).

[12] Ryabenko A.A., Klyuha O.A, Tymoshchuk V.S., Halych O.A., Poplavskiy D.M. Innovative tendencies in work management of energy systems by using HPSPP. Pvoceedings of X International Conference "Strategy of Quality in Industry and Education». Varna, Bulgaria, 2014. - $141-150$ ps.

[13] Riabenko A.A. (2003). Theoretical elements and methods of calculations of nearcritical fluid flows with a free surface. Thesis for academic degree of doctor of technical sciences: 05.23.16. Rivne, 2003. - 393 ps. (Ukrainian).

[14] Serre F. Contribution a l'étude des éconlements permanents et variables dans les canaux. La Houille Blanche. - 1953. - №3. - P.374 - 388, №6. - 830 - 872 ps. (French).

[15] Sukhomel G.I. Hydraulics. Kiev, Derzhsilhospvydav, 1933. - 280 ps. (Ukrainian).

\section{MODELOWANE MATEMATYCZNE I HYDRAULICZNE SKOKU FALOWEGO}

\section{Streszczenie}

Artykuł rozważa problemy matematycznego i hydraulicznego modelowania skoku falowego. Podano przypadki tworzenia się skoku falowego przy różnych pracy różnych budowli hydrotechnicznych. Jeśli określony skok falowy, szczególnie fali na wolnej powierzchni nie jest brany pod uwagę rozkład ciśnień, to otrzymane wyniki będą się znajdować pomiędzy projektowanym a rzeczywistym poziomem. Czynnik ten może powodować błędy w czasie projektowania, wznoszenia i eksploatacji budowli. Wskazuje to na konieczność opracowania wzorów i modeli do określania charakterystyk skoków falowych. Artykuł podaje różne wzory dla wolnej powierzchni i przepływów bliskokrytycznych, które zawierają skok falowy.

Niedokładności podanych różnych równań i ich rozwiązania ustalono, na podstawie opracowanych analiz. Wskutek tego, adresując istniejące błędne wyrażenia w stosunku do skoku falowego, trzeba brać pod uwagę nachylenie i krzywiznę linii nurtu w początkowej sekcji rozważanego zjawiska. Zaproponowano oryginalny model matematyczny bliskokrytycznego przepływu, który uwzględnia powyższy czynnik. Na podstawie tego modelu, opracowano odrębne równania z ogólnymi i szczegółowymi rozwiązaniami - dla zjawiska przepływu o wolnej powierzchni. 
Zaprezentowano również wyniki badań laboratoryjnych skoku falowego, które były podstawą analiz. Porównanie obliczeń teoretycznych z wynikami badań doświadczalnych pokazuje dobrą zbieżność wyników.

Słowa kluczowe: modelowanie, skok falowy, pojedyncza fala, konoidalna fala, modelowanie matematyczne, badania laboratoryjne

Przestano do redakcji:12.06.2015

Przyjęto do druku:1.12.2015

DOI: $10.7862 / \mathrm{rb} .2015 .162$ 